1998

\title{
Caddo Lake Archaeology: Phase I of Archaeological Investigations Along Harrison Bayou, Harrison County, Texas
}

Timothy K. Perttula

Heritage Research Center, Stephen F. Austin State University

Daniel J. Prikryl

Bo Nelson

Heritage Research Center, Stephen F. Austin State University

Sergio A. Iruegas

Follow this and additional works at: https://scholarworks.sfasu.edu/ita

Part of the American Material Culture Commons, Archaeological Anthropology Commons, Environmental Studies Commons, Other American Studies Commons, Other Arts and Humanities Commons, Other History of Art, Architecture, and Archaeology Commons, and the United States History Commons

Tell us how this article helped you.

This Article is brought to you for free and open access by the Center for Regional Heritage Research at SFA ScholarWorks. It has been accepted for inclusion in Index of Texas Archaeology: Open Access Gray Literature from the Lone Star State by an authorized editor of SFA ScholarWorks. For more information, please contact cdsscholarworks@sfasu.edu. 


\section{Caddo Lake Archaeology: Phase I of Archaeological Investigations Along Harrison Bayou, Harrison County, Texas \\ Creative Commons License \\ (c) (1) (8)}

This work is licensed under a Creative Commons Attribution-NonCommercial 4.0 International License 


\title{
CADDO LAKE ARCHAEOLOGY: \\ PHASE I OF ARCHAEOLOGICAL INVESTIGATIONS ALONG HARRISON BAYOU, HARRISON COUNTY, TEXAS
}

\author{
Timothy K. Perttula, Daniel J. Prikryl, Bo Nelson, and Sergio A. Iruegas
}

\section{Introduction}

An important part of the mission of the Caddo Lake Institute, Inc. and its Caddo Lake Scholars Program is the preservation and protection of the unique and irreplaceable cultural heritage of Caddo Lake and its bioregion, the Big Cypress Bayou watershed (Perttula 1993; Shellman 1993, 1995). The archaeology team of the Scholars Program is meeting these objectives with the initiation of the Harrison Bayou project by:

(a) offering archaeological education and training of teachers, students, and potential mentors,

(b) through fieldwork and research, identifying, assessing, and designating archaeological, historical, and cultural resources of the Caddo Lake bioregion, and

(c) formulating and implementing strategies for protecting the bioregion's significant cultural resources.

Archaeological investigations between 1993 and 1995 at Caddo Lake State Park (Skiles et al. 1995) represented the initial efforts of the Caddo Lake Institute's archaeology team to conduct an education/ training program, as well as to begin the process of identifying important archaeological and historical resources in the Caddo Lake Basin. The archaeology team also completed several archaeological projects in 1995-1996 in the Caddo Lake bioregion, particularly in the Ramsar Treaty lands (Caddo Lake Wildlife Management Area) and adjoining private land tracts, and now the Harrison Bayou project at Longhorn Army Ammunition Plant beckons. Students and mentors from the consortium of Caddo Lake Scholars Program universities and schools are being invited to participate in our archaeological efforts, which will represent the first concerted and long-term study of the bioregion's cultural environment.

The purposes of this work are three-fold: foremost is for our archaeological team to provide archeological education and training of students and potential mentors in the Caddo Lake Institute, Inc.'s projects in the Harrison Bayou lease lands at Longhorn Army Ammunition Plant, near the border of Texas and Louisiana. A second purpose is to identify important archaeological sites and archaeologically sensitive areas on the Harrison Bayou lands. This information is critical to identifying sites 
that are worthy of federal protection and designation efforts, and in insuring that future activities on lease lands have no effect on important archaeological sites. Finally, the study of the sites and material culture remains from sites identified on the Harrison Bayou lease lands, as well as the publication of the results of the investigations, will make available to the inter- ested public accurate information on the archaeological and historical resources in Caddo Lake wetlands and bottomland hardwood areas. This study effort also hopes to make evident why archaeological research is important on the Harrison Bayou lease lands, and why significant archaeological resources on these lands should be protected.

\section{Arrangements}

Arrangements and field schedules for the project are being coordinated by the Caddo Lake Institute, Inc., specifically Sara Kneipp of the Institute, and with the appropriate representatives of Longhorn Army Ammunition Plant. In addition to the authors (Archeological and Environ- mental Consultants team members), participants during the Phase I and II investigations will include Caddo Lake Scholar's Program participating teachers and students, Caddo Tribe of Oklahoma members (during our March 1998 field effort), and archaeology team leaders and mentors.

\section{Archaeological Reconnaissance along Harrison Bayou at Caddo Lake: Expectations and Methods}

We view the conduct of archaeological research along Harrison Bayou at Caddo Lake as a unique opportunity to learn about the past use of the Caddo Lake and Harrison Bayou wetland ecosystem. Because the Caddo Indian peoples lived in this bioregion from at least A.D. 800 to 1842 , knowledge gained on how they lived can contribute significant insights into how they achieved a sustainable use of wetlands and their associated flora and fauna.

Limited archaeological survey work has been conducted recently along Harrison Bayou as part of the inventory of cultural resources at the Longhorn Army Ammu- nition Plant (Cliff and Peter 1994; Cliff et al. 1995; Gadus et al. 1997), and at least 14 prehistoric and historic sites had been recorded within the 1400 acre lease area. Six of the sites have prehistoric Caddoan archaeological remains (41HS240, 404, $407,753,754$, and 755), and we proposed to relocate these sites as part of the work to obtain additional information on the use of the bioregion by the Caddo peoples.

Based on the archaeological investigations previously conducted in the Caddo Lake bioregion, there was every reason to expect evidence to be uncovered along Harrison Bayou that will demonstrate a lengthy use of the land, perhaps over a 
period of several thousand years. Prehistoric and historic sites were considered likely to occur on the following landforms along Harrison Bayou: alluvial terraces, floodplain knolls, flat pine-covered ridge crests overlooking the floodplain, ridge toe slopes and ridge landforms that extend into the floodplain, and elevated ground adjacent to Caddo Lake. Based on historically recorded high water levels of Caddo Lake of 173.09 feet amsl in 1812 and 1839 (Department of the Interior 1914), and the topographic setting, generally flat, moderately to well-drained, and elevated lands above 175-200 feet amsl have a high potential of containing archaeological resources.

Our archeological survey efforts in Phase I concentrated in these particular Harrison Bayou lease area settings. The methods employed in the archaeological survey consisted of a surface reconnaissance or walk-over of the area by the teams, supplemented by shovel tests $(30 \mathrm{~cm}$ in diameter and a maximum of $60-80 \mathrm{~cm}$ in depth) in high probability areas to locate buried sites and sites obscured by vegetation. The soil from the 84 shovel tests excavated to date was carefully screened through 1/4-inch hardware screen, looking for prehistoric and historic archaeological materials. When artifacts were found in shovel tests, additional shovel tests (up to 10 ) at two relocated sites (41HS240, the Harrison Bayou site, and 41HS407) were excavated in proximity to define the vertical and horizontal extent of the discovered archaeological site. Furthermore, when sites appeared to have the potential to contain middens, buried soils, features, or intact occupational deposits, $50 \times 50$ $\mathrm{cm}$ units were excavated in $20 \mathrm{~cm}$ levels on sites to gather more specific information on their archaeological character and integrity, and obtain controlled samples of artifacts. Chronometric samples (radiocarbon and oxidizable carbon ratio dates) were to be obtained if middens, features, buried soils, or intact occupational deposits were recognized during the investigations, and submitted for dating.

\section{Preliminary Findings of the Phase I Archaeological Investigations}

During the week-long effort in February 1998, 12 new prehistoric archaeological sites were located on the Harrison Bayou lease lands. Additionally, two previously recorded sites--41HS240 and 41HS407-were successfully relocated, and a number of shovel tests and $50 \times 50 \mathrm{~cm}$ units were excavated at the two sites to investigate possible midden areas and features. With the addition of the 12 previously undis- covered archaeological sites, there are now 26 historic and prehistoric sites identified in the Harrison Bayou lease lands, a relatively high density of one site per 53.8 acres; additional survey in Phase II of the project will certainly add additional archaeological sites to the lease land inventory. Salient aspects of the 14 prehistoric archaeological sites are presented in Table 1. 
Table 1. Phase I Archaeological Sites, Harrison Bayou Lease Lands

\begin{tabular}{|c|c|c|c|c|c|c|c|}
\hline Site & \# of ST & $\begin{array}{c}\text { \# of } \\
50 \times 50\end{array}$ & $\begin{array}{l}\text { Midden Deposits/ } \\
\text { Other Features }\end{array}$ & Ceramics & Lithics & Bone & $\begin{array}{c}\text { Artifact } \\
\text { Density } \\
(\mathrm{m})^{3}\end{array}$ \\
\hline $\mathrm{HS} 240$ & 6 & 3 & $\mathrm{x}$ & $\mathrm{x}$ & $\mathrm{X}$ & & 347 \\
\hline HS407 & 17 & 1 & $\mathrm{X}$ & $\mathrm{X}$ & $\mathrm{X}$ & $\mathrm{X}$ & $155^{*}$ \\
\hline$\# 1 * *$ & 3 & & $?$ & $\mathrm{X}$ & $\mathrm{X}$ & $\mathrm{X}$ & 231 \\
\hline$\# 2$ & 2 & & & $\mathrm{x}$ & & $\mathrm{X}$ & 63 \\
\hline$\# 3$ & 2 & & & & $\mathrm{X}$ & & 29 \\
\hline$\# 4$ & 2 & & & & $\mathrm{X}$ & & 17 \\
\hline$\# 5$ & 1 & & & & $\mathrm{X}$ & & 25 \\
\hline$\# 6$ & 1 & & & & $\mathrm{X}$ & & 41 \\
\hline$\# 7$ & 3 & & & & $\mathrm{X}$ & & 48 \\
\hline$\# 8$ & 1 & & & & $\mathrm{x}$ & & 22 \\
\hline$\# 9$ & 2 & & & & $\mathrm{X}$ & & 20 \\
\hline$\# 10$ & 1 & & & & $\mathrm{X}$ & & 11 \\
\hline \#11 & 1 & & & & $\mathrm{X}$ & & 20 \\
\hline$\# 12$ & 1 & & & & $\mathrm{X}$ & & 45 \\
\hline
\end{tabular}

$\mathrm{X}=$ present

* Does not include 3 historic artifacts (1 square nail, 1 wire nail, 1 plain whiteware sherd)

** State of Texas trinomials have not yet been assigned

Two of the 14 sites, and possibly a third, contain prehistoric Caddoan midden deposits and features (Table 1): 41HS240, $41 \mathrm{HS} 407$, and Site \#1. Site $41 \mathrm{HS} 240$ is located on a high ridge along the east side of Harrison Bayou, while the other two sites are ideally situated on a distinctive ridge (or island) surrounded by swamp near where Harrison Bayou enters the now-drowned valley of Big Cypress Bayou.
These three sites have high densities (ca. 100-200 sherds per cubic meter) of Middle to Late Caddoan ceramics, mainly brushed, ridged, and parallel incised sherds from utility vessels, lithic debris and tools (including a contracting stem arrowpoint from $41 \mathrm{HS} 240$ and a small Gary dart point from Site \#1), burned and unburned animal bone, burned clay and daub, and small amounts of fire-cracked rock. A burned rock feature was 
Volume 9, Number 1

encountered between $20-33 \mathrm{~cm}$ bs in the shovel testing at 41HS407. All of these attributes suggest that these three sites are habitation sites (small hamlets and/or farmsteads) with preserved Caddoan structures (houses, arbors, and ramadas), associated trash midden deposits, and outdoor cooking and heating features. These archaeological sites clearly have the potential to contribute new and important information on a variety of research issues developed by the Texas State Historic Preservation Office (Kenmotsu and Perttula 1993:69-187) concerning the prehistoric Caddoan settlement of the Caddo Lake bioregion.

One other site (Site \#2) contains Caddoan ceramics and bone, but in low densities, and no midden deposits were identified at it during limited shovel testing (Table 1).
The preservation of ceramics and bone does suggest that features and trash deposits are likely preserved at the site. Additional shovel testing is planned at Site \#2 during the Phase II investigations to further assess its research potential.

The remaining 10 prehistoric sites have only prehistoric lithic artifacts, including low densities of lithic debris (the remains of stone tool knapping) and a ground stone mano from Site \#7 along Harrison Bayou. These sites occur on a variety of ridge and terrace landforms, usually in areas of deeper sand, and they may represent limited activity foraging and hunting camps occupied during Archaic, Woodland, and Caddoan times. Further investigations are planned at a sample of these sites to clarify their age and archaeological character.

\section{Concluding Remarks}

From this long-term research effort, we hope to achieve the following: (1) the identification of historic and prehistoric Native American sites and historic 19th and 20th century Anglo-American sites; (2) the completion and publication of a final report of findings; and (3) the development of recommendations to the Caddo Lake Institute, Inc. and the Department of Army concerning sites worthy of federal protective designations on the Harrison Bayou lease area on Longhorn AAP lands, on archeological management needs for the lease area, as well as recommendations for future phases of work over the course of the 30 year lease by the Institute. From the work completed to date, we have already identified 41HS240 and 41HS407 as significant Caddo Indian archaeological resources that are worthy of inclusion in the National Register of Historic Places (NRHP) and warrant designation as State Archeological Landmarks. Site \#1 appears to also possess research potential, but further work will be needed to determine if it is worthy of inclusion in the NRHP. The research potential of the other 11 prehistoric archaeological sites also remains to be established. 


\section{References Cited}

Cliff, Maynard B. and Duane E. Peter (editors)

1994 Archeological Survey of Selected

Portions of the Longhorn Army Ammunition Plant, Harrison County, Texas, 1989-1992. Miscellaneous Report of Investigations Number 38. Geo-Marine, Inc., Plano.

Cliff, Maynard B., Steve M. Hunt, Floyd Kent, Melissa M. Green, and Duane E. Peter

1995 Archeological Survey of 1993-1994

Timber Harvesting Areas, Longhorn Army Ammunition Plant, Harrison County, Texas. Miscellaneous Report of Investigations Number 71. Geo-Marine, Inc., Plano.

Department of the Interior

1914 Examination of Ferry Lake, Caddo Parish, Louisiana. Supervisor of Surveys, Commissioner of the General Land Office, Washington, D.C.

Gadus, E. F., M. D. Freeman, and R. C. Fields

1997 Archeological Survey of 319

Hectares at the Longhorn Army Ammunition Plant, Harrison County, Texas. Reports of Investigations No. 119. Prewitt and Associates, Inc., Austin.

Kenmotsu, Nancy A. and Timothy K. Perttula (editors)

1993 Archeology in the Eastern Planning Region, Texas: A Planning Document.
Cultural Resource Management Report 3. Texas Historical Commission, Department of Antiquities Protection, Austin.

Perttula, Timothy K.

1993 The Caddo Lake Scholars Program Seminar and What It Means for the Protection of Caddoan Archeological Resources. Caddoan Archeological Newsletter IV(2):2-4.

Shellman, Dwight K., Jr.

1993 Overview of Unifying Themes. In

The Caddo Lake Scholars Seminar and Awards Presentation Briefing Booklet, pp. 70-74. Isis Fund, Caddo Lake Institute, East Texas Baptist University, Wiley College, Stephen F. Austin State University, and Uncertain Audubon Society of Texas and Louisiana.

1995 A Mission Statement of Caddo Lake Institute regarding its participation in the 1995 Caddo Conference. Paper presented at the 37 th Caddo Conference, Austin, Texas.

Skiles, Bob D., Timothy K. Perttula, Bo Nelson, and Mike Turner 1995 Archeological Investigations of the Caddo Lake Scholars Program at Caddo Lake State Park, Harrison County, Texas, 1993-1995. Special Publication No. 2. Friends of Northeast Texas Archaeology, Austin and Pittsburg. 